\title{
Casting a Meaningful Ballot: Applying One-Person, One-Vote to Judicial Elections Involving Racial Discrimination
}

\author{
Andrew S. Marovitz
}

For many citizens, the American electoral system evokes images of voters casting their ballots in fair and open elections for candidates of their choice. The Fourteenth ${ }^{1}$ and Fifteenth Amendments, ${ }^{2}$ which prohibit voting discrimination on the basis of race, ${ }^{3}$ cover every election conducted in national and state politics. ${ }^{4}$ These amendments also outlaw discriminatory practices that dilute minority votes. ${ }^{5}$ Despite the ratification of the Fourteenth Amendment in 1868 and the Fifteenth Amendment in 1870, some states continued to harass citizens, particularly blacks, who attempted to exercise their constitutional right to vote. These states relied on less obvious but equally effective forms of discrimination-stuffing ballot boxes, ${ }^{6}$ gerrymandering electoral boundaries, ${ }^{7}$ and enforcing grandfather clauses $^{8}$ - to disenfranchise blacks. It was only after the Supreme Court's decision in Baker v. Carr ${ }^{2}$-holding that Tennessee's apportionment of seats in its General Assembly was a justiciable issue-that citizens could successfully challenge electoral schemes diluting their votes. Still, as recently as 1963 , five southern states levied poll taxes that had a significant impact on black voter registration. ${ }^{10}$

1. U.S. CoNST. amend. XIV, $\$ 1$ ("[No State shall] deny to any person within its jurisdiction the equal protection of the laws.").

2. U.S. ConST. amend. XV, § 1 ("The right of citizens of the United States to vote shall not be denied or abridged by the United States or by any State on account of race, color, or previous condition of servitude.").

3. See, e.g., Louisiana v. United States, 380 U.S. 145 (1965).

4. Reynolds v. Sims, 377 U.S. 533 (1964); Hennings v. Grafton, 523 F.2d 861 (7th Cir. 1975).

5. See, e.g., Reynolds, 377 U.S. at 554-55; United States v. Mosley, 238 U.S. 383, 386 (1915). Racial vote dilution, often dubbed minority vote dilution, occurs whenever the combination of election practices and bloc voting results in the diminution of the voting strength of a racial minority group. Davidson, Minority Vote Dilution, in Minority Vote Dilution 4 (C. Davidson ed. 1984).

6. See, e.g., United States v. Saylor, 322 U.S. 385 (1944); Ex parte Siebold, 100 U.S. 371 (1879).

7. Gomillion v. Lightfoot, 364 U.S. 339, 347 (1960); see, e.g., Kousser, The Undermining of the First Reconstruction: Lessons for the Second, in Minority Vote Dilution, supra note 5, at 31-33.

8. See, e.g., Lane v. Wilson, 307 U.S. 268, 275-77 (1939); Guinn v. United States, 238 U.S. 347 , 364-65 (1915).

9. 369 U.S. 186 (1962).

10. Matthews \& Prothro, Political Factors and Negro Voter Registration in the South, 57 AM. Pol. ScI. Rev. 355, 357-58 (1963). 
After many of these schemes had been exposed, the Supreme Court developed the one-person, one-vote doctrine ${ }^{11}$ to deal comprehensively with discriminatory electoral practices. Put generally, this doctrine emanates from the "personal right to cast a vote that [is] the mathematical equivalent of the vote cast by any other member of the same constituency." ${ }^{12}$ Deriving its analysis from the Fifteenth and Nineteenth Amendments, ${ }^{13}$ the Court announced that the equal protection clause of the Fourteenth Amendment requires that every ballot be weighed equally: one-person, one-vote. ${ }^{14}$

Although many of the early one-person, one-vote cases were brought on behalf of claimants alleging discrimination in legislative elections, the Court generally expanded the scope of the principle to include the elections of other governmental officials. ${ }^{15}$ It refused, however, to extend the rule to elections of state court judges. In Wells $v . E d w a r d s,{ }^{16}$ the Supreme Court affirmed without opinion the district court's decision that "the concept of one-man, one-vote apportionment does not apply to the judicial branch of the government."17 In essence, judges could be elected from districts differing significantly in size.

While the Court applied the one-person, one-vote principle to ensure equal populations in legislative-type elections, Congress passed the Voting Rights Act of $1965^{18}$ to deal with racial discrimination in all elections. ${ }^{19}$ The Act prohibits the use of discriminatory election practices nationwide. ${ }^{20}$ Unlike their treatment of the one-person, one-vote principle, fed-

11. The Court and various commentators also have referred to the doctrine as the "one-man, onevote doctrine." Recognizing the 19th Amendment, the Court has refrained from using this formulation since 1973. See infra note 13; Mahan v. Howell, 410 U.S. 315, 319, modified, 411 U.S. 922 (1973).

12. L. Tribe, American Constitutional Law $\S 13-3$, at 1064 (2d ed. 1988). This principle also guarantees that members of state legislatures represent roughly the same number of constituents. See, e.g., Reynolds v. Sims, 377 U.S. 533, 568 (1964); Gray v. Sanders, 372 U.S. 368, 382 (1963) (Stewart, J., concurring) ("Within a given constituency, there can be room for but a single constitutional rule-one voter, one vote."); United States v. Classic, 313 U.S. 299 (1941).

13. The Nineteenth Amendment provides, in pertinent part: "The right of citizens of the United States to vote shall not be denied or abridged by the United States or by any State on account of sex." U.S. Const. amend. XIX.

14. Gray v. Sanders, 372 U.S. at 379-80.

15. See infra Section I(B).

16. 347 F. Supp. 453 (M.D. La. 1972), affd mem., 409 U.S. 1095 (1973).

17. 347 F. Supp. at 454; see Voter Information Project, Inc. v. City of Baton Rouge, 612 F.2d 208, 211 (5th Cir. 1980); Martin v. Mabus, 700 F. Supp. 327, 332 (S.D. Miss. 1988). It should be noted that the petitioner in Wells relied upon principles of apportionment, not racial discrimination.

18. Pub. L. No. $89-110,79$ Stat. 437 (codified as amended at 42 U.S.C. $\$ \S 1971,1973$ to 1973bb-1 (1976)), amended by Voting Rights Act Amendments of 1982, Pub. L. No. 97-205, 96 Stat. 131,134 (codified at 42 U.S.C. $\$ \S 1971,1973$ to 1973 bb-1 (1982)).

19. The goals of the Voting Rights Act are outlined in the Report of the Senate Judiciary Committee. See S. ReP. No. 417, 97th Cong., 2d Sess. 5 [hereinafter SENATE REPoRT], reprinted in 1982 U.S. Code Cong. \& Admin. News 177, 182.

20. Section 2 of the amended Act provides, in pertinent part:

(a) No voting qualification or prerequisite to voting or standard, practice, or procedure shall be imposed or applied by any State or political subdivision in a manner which results in a denial or abridgement of the right of any citizen of the United States to vote on account of race or color. ... 
eral courts recently have applied the Act to state judicial elections ${ }^{21}$ when such elections are challenged on grounds of racial discrimination. In both Chisom v. Edwards ${ }^{22}$ and Mallory v. Eyrich, ${ }^{23}$ federal courts of appeals have reversed district court holdings that the Act did not apply to elections for state court judges.

This recent interpretation of the Voting Rights Act is important but, unfortunately, not comprehensive. Under this interpretation, the Act fails to protect adequately the voting rights of black ${ }^{24}$ citizens casting ballots in judicial elections, because it has been applied only to prohibit the debasement of minority votes within discrete judicial electoral districts. The Act has not been interpreted to outlaw the disproportionate allotment of elected judges across a state; ${ }^{25}$ while the one-person, one-vote doctrine directly addresses this problem, the Court in Wells refused to extend this doctrine to judicial elections. In effect, this loophole permits state election officials bent on disenfranchising blacks to apportion judges so that white citizens are "represented" by more judges than are black citizens. Although this would not dilute the votes of blacks with respect to whites in any one political subdivision-and therefore would not violate the strictures of the Voting Rights Act as currently interpreted-it effectively would reduce the influence of blacks on both judicial elections and state court jurisprudence. In addition, unlike the one-person, one-vote doctrine, the Act does not require that state governments maintain population deviations between judicial districts below specific levels. ${ }^{26}$

Given these loopholes in voting rights advancements, this Note proposes that courts extend the application of the one-person, one-vote standard to judicial elections when such elections are challenged on grounds of racial

(b) A violation of subsection (a) of this section is established if, based on the totality of circumstances, it is shown that the political processes leading to nomination or election in the State or political subdivision are not equally open to participation by members of a class of citizens protected by subsection (a) of this section in that its members have less opportunity than other members of the electorate to participate in the political process. . . .

42 U.S.C. \$ 1973 (1982).

21. Because most state constitutions allow state legislatures to draw independent districts for legislative and judicial elections, the reconstruction of legislative boundaries to comply with $\S 2$ had little effect on judicial boundaries or elections, and claimants were forced to bring separate challenges to judicial districting. See generally Legislative Drafting Research Fund of Columbia UnIVeRSity, Constitutions of the United States: National and State (1988) (survey of state constitutions).

22. 839 F.2d 1056 (5th Cir. 1988), rev'g 659 F. Supp. 183 (E.D. La. 1987), cert. denied, 109 S. Ct. 390 (1988).

23. 839 F.2d 275 (6th Cir. 1988), rev'g 666 F. Supp. 1060 (S.D. Ohio 1987).

24. This Note discusses racial discrimination against black voters because violations of both the one-person, one-vote doctrine and the Voting Rights Act have come primarily at the expense of blacks. However, the discriminatory practices outlined in this Note have been used to dilute the votes of other racial and ethnic minorities as well. As such, the proposal offered here should be interpreted to apply to any such group claiming protection.

25. Courts recently interpreting the Act have dealt exclusively with jurisdictional boundaries, ignoring the number of judges located within each district. See infra text accompanying notes 75-78.

26. See, e.g., Martin v. Mabus, 700 F. Supp. 327, 331-32 (S.D. Miss. 1988). For a discussion of de minimis deviations, see infra note 116 and accompanying text. 
discrimination. ${ }^{27}$ Section I will summarize the development of the oneperson, one-vote doctrine and its application to elected judges. Section II will then introduce the practical limitations of this doctrine as applied to racial discrimination cases, address the deficiencies of the Voting Rights Act in remedying potential discrimination, and emphasize the importance of proper judicial apportionment within the context of state court elections. Drawing upon this foundation, Section III will propose the adoption of a close scrutiny standard in one-person, one-vote challenges to judicial elections based upon race. ${ }^{28}$

\section{The One-Person, One-Vote Principle}

\section{A. Origins of the Rule: The Decision to Enter the Political Thicket}

In 1962, the Supreme Court first entered "the political thicket"29 of reapportionment by deciding in Baker v. Carr that federal courts were competent to hear equal protection challenges to schemes of apportionment. The following year, the Court extended this holding to the realm of substantive law by striking down a statewide primary system of election that favored ballots cast in rural areas over those cast in urban areas. This case, Gray v. Sanders, ${ }^{30}$ constituted a great achievement in the development of voting rights. Justice Douglas, writing for the Court, summarized: "The conception of political equality from the Declaration of Independence, to Lincoln's Gettysburg Address, to the Fifteenth, Seventeenth, and Nineteenth Amendments can mean only one thing-one person, one vote." 31

The Court next extended this analysis to federal congressional districts in Wesberry v. Sanders. ${ }^{32}$ There, the Court applied Article I, section 2 of the Constitution-providing that representatives be selected "by the People of the several States"- to strike down statutes that created disproportionate electoral districts. "To say that a vote is worth more in one dis-

27. Of course, this problem would be resolved if the Court simply abandoned Wells and allowed individuals to bring one-person, one-vote challenges to non-discriminatory judicial districts. See infra note 51. This Note provides analytical support for such an abandonment. See infra Section II(C). However, even under the current legal regime, this Note argues that district courts would not violate the Wells doctrine by applying the one-person, one-vote principle to claims of racial discrimination in judicial elections.

28. One important caveat must be added here. In no way does this Note recommend that each state adopt elections as its method of selecting judicial officers. This Note argues simply that the oneperson, one-vote principle should apply in racial challenges to judicial elections in states that have adopted elections as their method of judicial selection.

29. Justice Frankfurter was among the first to use this term. See Colegrove v. Green, 328 U.S. 549, 556 (1946); see also id. at 552 (Court cannot strike down state apportionment scheme because of scheme's "peculiarly political nature").

30. 372 U.S. 368 (1963).

31. Id. at 381 .

32. 376 U.S. 1 (1964).

33. Id. at 7-8. Claimants in Wesberry were citizens of Fulton County, Georgia, and were registered to vote in the Fifth Congressional District. This district was composed of 823,680 people, while 
trict than in another would not only run counter to our fundamental ideas of democratic government, it would cast aside the principle of a House of Representatives elected 'by the People'. . .."34

The final major development of the 1960s reapportionment revolution came in Reynolds v. Sims. ${ }^{35}$ In Reynolds, the Court invalidated a state legislative apportionment system ${ }^{36}$ and held that "the Equal Protection Clause requires both houses of a state legislature to be apportioned on a population basis ...."3z On the same day, in Lucas v. Forty-Fourth General Assembly ${ }^{38}$ the Court relied on Reynolds to rule that impermissible apportionment schemes cannot be preserved through a referendum of a state's citizens. $^{39}$

\section{B. The Scope of the Rule}

With the development of the one-person, one-vote rule, the Court had to determine to which elections the rule applied. At first, the Court extended the rule to both houses of the state legislature in Reynolds and to elected state executive officers in Gray $v$. Sanders. ${ }^{40}$ Plaintiffs attempted to broaden further the application of the rule to other units of government, and sometimes succeeded. One of the first attempts came in Sailors v. Board of Education, ${ }^{41}$ where Michigan voters challenged the apportionment of members of the county board of education as a violation of the one-person, one-vote principle. The Court rejected this challenge for two reasons. First, the one-person, one-vote rule did not apply because plaintiffs did not challenge the election of local school board officials, but instead challenged the subsequent appointment of county officials. ${ }^{42}$ Second, the rule did not apply because the offices challenged were "nonlegislative" in nature. ${ }^{43}$

the average population of each district in Georgia was only 394,312. Id. at 2. In effect, then, members of Congress from the Fifth District represented more than twice as many people as did the average Georgia representative.

34. Id. at 8; see The Federalist No. 57, at 351 (J. Madison) (C. Rossiter ed. 1961) (electors of members of Congress are to be great body of "the people" of United States).

35. 377 U.S. 533 (1964).

36. Since the claimants challenged state legislative districting, they grounded their claim in the equal protection clause, instead of Article I, $\S 2$ of the Constitution. Id. at 537.

37. Id. at 576.

38. 377 U.S. 713 (1964).

39. Id. at 734-36; id. at 736 ("An individual's constitutionally protected right to cast an equally weighted vote cannot be denied even by a vote of a majority of a State's electorate . . . .").

40. 372 U.S. 368 (1963).

41. 387 U.S. 105 (1967).

42. Id. at 106, 111. Delegates from local school boards, not school electors, appointed the county school board members. Id. at 109.

43. Id. at 111. On the same day, the Court upheld an election scheme for Virginia Beach's city council. Dusch v. Davis, 387 U.S. 112 (1967). In that case, the Court found it irrelevant that council members were elected from disproportionately-sized boroughs because each council member represented the population of the entire city. Hence, the election practice did not violate the one-person, one-vote rule. 
Plaintiffs were more successful in Avery $v$. Midland County, ${ }^{44}$ in which the Gourt applied to local governments the one-person, one-vote rule expounded in Reynolds $v$. Sims. Justice White, writing for the Court, announced another extension of the rule: "Our decision today is only that the Constitution imposes one ground rule for the development of arrangements of local government: a requirement that units with general governmental powers over an entire geographic area not be apportioned among single-member districts of substantially unequal population."45 The fact that the commissioners in Avery were able to make substantive decisions affecting the entire community weighed heavily on the Court's decision to strike down the districting scheme on the one-person, one-vote principle. ${ }^{48}$

The scope of this principle was clarified, finally, in Hadley v. Junior College District. ${ }^{47}$ There, the Court surveyed the existing case law on the reach of the rule and concluded that even junior college school districts must apportion representatives evenly. The Court based its holding on the importance and complexity of the governmental powers granted to elected junior college trustees. ${ }^{48}$ More important, however, was the standard the Gourt declared to guide future decisions:

[A]s a general rule, whenever a state or local government decides to select persons by popular election to perform governmental functions, the Equal Protection Clause of the Fourteenth Amendment requires that each qualified voter must be given an equal opportunity to participate in that election, and when members of an elected body are chosen from separate districts, each district must be established on a basis that will insure, as far as is practicable, that equal numbers of voters can vote for proportionally equal numbers of officials. ${ }^{49}$

This standard currently forms the basis for whether the one-person, onevote standard applies to a specific type of election. ${ }^{50}$

\section{G. The Hadley Standard and Elected Judges}

During the development of the Hadley standard, plaintiffs attempted to challenge judicial elections under the one-person, one-vote principle.

44. 390 U.S. 474 (1968). In Avery, a taxpayer brought suit to challenge the districting scheme of county precincts of significantly differing populations.

45. Id. at $485-86$ (emphasis supplied).

46. Id. at $484-86$.

47. 397 U.S. $50(1970)$.

48. Id. at $53-54$.

49. Id. at 56 .

50. This standard has been applied recently. See, e.g., Morris v. Board of Estimate, 707 F.2d 686 (2d Cir. 1983) (principle applies because board is selected by popular election and performs general governmental functions), remanded, 647 F. Supp. 1463 (E.D.N.Y. 1986), affd, 831 F.2d 384, 388 (2d Gir. 1987) (clarifying requirements of equal protection clause), aff d, $109 \mathrm{~S}$. Ct. 1433 (1989); Hurlbut v. Scheetz, 804 F.2d 462 (8th Cir. 1986) (equal protection clause requires application of oneperson, one-vote principle to elected school board). 
Many of these challenges have been systematically and, in the view of this Note, mistakenly rebuffed by the federal courts.

The first such challenge came in Stokes $v$. Fortson, ${ }^{\text {s1 }}$ in which the plaintiffs challenged Georgia statutes that governed the selection of elected state judges. Those statutes allowed a majority of the state's voters to oust a judge elected by a particular circuit. ${ }^{\mathbf{5 2}}$ The plaintiffs alleged that this scheme violated the one-person, one-vote principle. ${ }^{53}$ The court rejected this claim, noting first that the Georgia election practice neither resulted in discrimination among voters nor promoted unequal weighing of votes. ${ }^{54}$ More important, however, was the court's second conclusion:

[E]ven assuming some disparity in voting power, the one man-one vote doctrine, applicable as it now is to selection of legislative and excutive [sic] officials, does not extend to the judiciary. Manifestly, judges . . . are not representatives in the same sense as are legislators or the executive. Their function is to administer the law, not to espouse the cause of a particular constituency. ${ }^{55}$

Stokes served as the progenitor of a line of cases based upon precisely this reasoning. ${ }^{.68}$

Against this backdrop of unanimity, the Supreme Court heard one equal protection challenge to these judicial elections. In Wells v. Edwards, ${ }^{87}$ the district court held that "the concept of one-man, one-vote apportionment does not apply to the judicial branch of the government."'s8

51. 234 F. Supp. 575 (N.D. Ga. 1964) (per curiam). This case and others involving elected judges are summarized in Note, The Equal-Population Principle: Does it Apply to Elected Judges?, 47 Notre Dame Law. 316 (1971). This note reviewed the case law in existence before the Supreme Court's decision in Wells, see supra note 16, infra notes 57-61 and accompanying text, and concluded briefly that under some circumstances the one-person, one-vote principle should apply to the elected judiciary. Neither this note nor the Court's decision, however, specifically addressed the question of race in these elections.

52. 234 F. Supp. at 577 .

53. Id.

54. Id.

55. Id.

56. Chronologically, these cases include Buchanan v. Rhodes, 249 F. Supp. 860, 865 (N.D. Ohio) ("Judges do not represent people, they serve people. They must, therefore, be conveniently located to those people whom they serve."), appeal dismissed, 385 U.S. 3 (1966); New York State Ass'n of Trial Lawyers v. Rockefeller, 267 F. Supp. 148, 153 (S.D.N.Y. 1967) (same); Kail v. Rockefeller, 275 F. Supp. 937 (E.D.N.Y. 1967) (presence of unequal court delay insufficient to require apportionment on one-person, one-vote basis); De Kosenko v. New York, 311 F. Supp. 126, 129 (S.D.N.Y. 1969) (same), affd, 427 F.2d 351 (2d Cir. 1970); Holshouser v. Scott, 335 F. Supp. 928, 930-32, 934 (M.D.N.C. 1971) (republican form of government does not require election of state court judges; these elections need not conform to one-person, one-vote standard), affd mem., 409 U.S. 807 (1972); Buchanan v. Gilligan, 349 F. Supp. 569, 571 (N.D. Ohio 1972) (state judiciary not responsible for achieving representative government); and Gilday v. Board of Elections, $472 \mathrm{~F} .2 \mathrm{~d} \mathrm{214,} 217$ (6th $\mathrm{Cir}$. 1972) (one-person, one-vote principle not applicable to state judiciary).

57. 347 F. Supp. 453 (M.D. La. 1972), affd mem., 409 U.S. 1095 (1973).

58. $347 \mathrm{~F}$. Supp. at 454 . Some commentators also have argued that judges are wholly removed from the processes of politics and, therefore, from the one-person, one-vote principle: "They [courts and judges] make no law, they establish no policy, they never enter into the domain of popular action." "H. Abraham, The Judicial Process 320 (3d ed. 1975) (statement of Justice David 
The Supreme Court summarily affirmed, over a sharp dissent by Justice White, joined by Justices Douglas and Marshall. Justice White charged that the Louisiana constitutional provision under attack led to severe population disparities between districts, ${ }^{58}$ and maintained that the Court's line of decisions from Reynolds to Hadley supported the application of the one-person, one-vote principle to judicial elections. Justice White also relied upon the general rule derived from Hadley, which requires that any election for an official performing governmental functions comply with the one-person, one-vote doctrine. ${ }^{60}$ White argued that the district court's construction of the phrase "persons . . . to perform governmental functions" as limited to "officials who performed legislative or executive type duties" was overly restrictive: "Judges are not private citizens who are sought out by litigious neighbors to pass upon their disputes. They are state officials, vested with state powers and elected (or appointed) to carry out the state government's judicial functions. As such, they most certainly 'perform governmental functions." "B1 The Court has not yet responded to Justice White's analysis, but it is generally understood that apportionment principles do not extend to judicial elections. ${ }^{62}$

\section{The Limitations of Applying Principles of Racial Discrimination to the Gurrent One-Person, One-Vote DOCTRINE}

After the Court affirmed Wells, lower federal courts deferred to the Supreme Court's explication of the scope of the one-person, one-vote principle. ${ }^{63}$ The courts, however, have interpreted Wells to preclude application of the principle to any state judicial election, despite the Wells Court's concern only with principles of apportionment and not racial discrimination. Indeed, the line of cases discussed earlier ${ }^{64}$-from Stokes $v$. Fortson to Gilday v. Board of Electors-does not consider in any detail

Brewer). Cf. G. White, The American Judicial Tradition 109-28 (expanded ed. 1988) (discussing relationship between politics and jurisprudence).

59. 409 U.S. at 1095 (White, J., dissenting).

60. Id. at 1095-96 (quoting Hadley v. Junior College Dist., 397 U.S. 50, 56 (1970)). See Hadley, 397 U.S. at 55:

If there is any way of determining the importance of choosing a particular governmental official, we think the decision of the State to select that official by popular vote is a strong enough indication that the choice is an important one. This is so because in our country popular election has traditionally been the method followed when government by the people is most desired.

61. Wells, 409 U.S. at 1096-97 (White, J., dissenting).

62. See, e.g., Butler, Reapportionment, the Courts, and the Voting Rights Act: A Resegregation of the Political Process?, 56 U. CoLo. L. REv. 1, 11 n.34 (1984); Charo, Designing Mathematical Models to Describe One-Person, One-Vote Compliance by Unique Governmental Structures: The Case of the New York City Board of Estimate, 53 FordHAM L. Rev. 735, 762 n.166 (1985).

63. See, e.g., Voter Information Project v. City of Baton Rouge, 612 F.2d 208, 211 (5th Cir. 1980) (bound by Court's decision in Wells); Martin v. Mabus, 700 F. Supp. 327, 332 (S.D. Miss. 1988) (same).

64. See supra notes 51-56 and accompanying text. 
claims of racial discrimination. It is in this area that courts should apply the one-person, one-vote principle to judicial elections.

\section{A. Examining the Case Law}

Many of the principles upon which the Court relied to develop the oneperson, one-vote principle-from Gray $v$. Sanders to Reynolds $v$. Sims-were derived from early racial discrimination cases. In Gray $v$. Sanders, for example, the Court relied upon Terry v. Adams ${ }^{\mathrm{65}}$ and Ex parte Yarbrough, ${ }^{68}$ both of which protected the right of black citizens to cast a meaningful ballot. The Reynolds Court also cited Ex parte Yarbrough and Terry v. Adams, as well as Guinn v. United States, ${ }^{67}$ Lane v. Wilson, ${ }^{68}$ Gomillion v. Lightfoot, ${ }^{69}$ Nixon v. Herndon, ${ }^{70}$ Nixon v. Condon, ${ }^{71}$ and Smith $v$. Allwright, ${ }^{72}$ each of which deals principally with issues of racial discrimination. ${ }^{73}$

Despite the subsequent elevation of the one-person, one-vote rule to a fundamental right under the Constitution, the force of these early racial discrimination cases should not be disregarded outside the apportionment context. To be sure, the one-person, one-vote principle was extended to apply to non-discrimination, apportionment cases, but its derivation from the Fourteenth Amendment-which "was passed . . . with a special intent to protect the blacks from discrimination against them"74-should not be ignored simply because it was later subsumed within the framework of non-discriminatory apportionment. When the Wells district court, for example, rejected the application of the one-person, one-vote rule to judicial elections, it relied upon principles of apportionment without contemporaneously considering racial discrimination. It is precisely when racial discrimination is at issue, however, that Wells-concerned only with issues of apportionment-need not apply.

The circuit courts in both Mallory v. Eyrich and Chisom v. Edwards

65. 345 U.S. 461 (1953) (striking down white voter association's pre-primary because it deprived black citizens of right to vote on account of race).

66. 110 U.S. 651 (1884) (Fifteenth Amendment confers right to vote upon all black citizens).

67. 238 U.S. 347 (1915) (state election officials who deprive blacks of right to vote are indictable under state law).

68. 307 U.S. 268 (1939) (upholding statute imposing liability on persons who deprive blacks of their right to vote).

69. 364 U.S. 339 (1960) (reversing district court's dismissal of case in which blacks' votes were diluted through gerrymandering).

70. 273 U.S. 536 (1927) (black citizen may seek damages for denial of right to vote in primaries).

71. 286 U.S. 73 (1932) (same).

72. 321 U.S. 649 (1944) (forbidding party membership discrimination that prohibited blacks from voting in primaries).

73. Justice O'Connor recently made a similar point in her concurrence in Davis v. Bandemer, 478 U.S. 109 (1986) (Indiana Democrats did not satisfy threshold showing of discriminatory vote dilution). Justice O'Connor argued that the Court's line of "racial gerrymandering cases" provides unique protection for the victims of racial discrimination. Id. at 151-52 (O'Connor, J., concurring).

74. Nixon v. Herndon, 273 U.S. 536, 541 (1927); see Strauder v. West Virginia, 100 U:S. 303 (1879); The Slaughter House Cases, 83 U.S. (16 Wall.) 36 (1873). 
recognized the distinction between racial discrimination and apportionment, but refused to consider its implications because they were able to decide these cases on statutory grounds. ${ }^{75}$ In Mallory, for instance, the court noted that the one-person, one-vote principle enunciated in Reynolds v. Sims concerned "the population of different voting districts, not their racial composition." apportionment cases, noting that the plaintiffs brought a claim under the Voting Rights Act, not under the one-person, one-vote principle. ${ }^{77}$ Similarly, the Chisom court concluded that

the district court's reliance on Wells . . . is misplaced as we are not concerned with a complaint seeking reapportionment of judicial districts on the basis of population deviations between districts. Rather, the complaint in the instant case involves claims of racial discrimination resulting in vote dilution under section 2 of the Voting Rights Act. . . . . ${ }^{78}$

Each court properly refused to deal with the constitutional issue of oneperson, one-vote, largely because the case could be decided on section 2 grounds. Nonetheless, the relief awarded by courts in response to plaintiffs who successfully rely upon the Voting Rights Act (such as the plaintiffs in Chisom and Mallory) may be illusory if election officials are later able to circumvent the Voting Rights Act by allocating more judges in certain areas without diluting popular votes across the state.

\section{B. The Potential for Malapportionment}

There are no pending one-person, one-vote cases that charge state offcials with malapportioning judges to circumvent the strictures of the Voting Rights Act. This is not surprising and does not suggest that state officials may not have powerful incentives to act in such a manner in the near future. Until recently, state officials bent on electoral discrimination were not compelled to rely upon the type of malapportionment discussed in this Note, for they could simply define judicial districts in a manner that diluted the votes of black citizens. Two district courts had rejected claims that section 2 of the Voting Rights Act ${ }^{79}$ - prohibiting vote dilution based upon race-protected blacks casting ballots in judicial elections. ${ }^{80}$ Only

75. Cf. Ashwander v. Tennessee Valley Authority, 297 U.S. 288, 347 (1936) (Brandeis, J., concurring) (Court will not pass on constitutional question when it can properly dispose of case on statutory grounds).

76. 839 F.2d 275, 277-78 (6th Cir. 1988).

77. Id. at 278 .

78. 839 F.2d 1056, 1061 (5th Cir.), cert. denied, 109 S. Ct. 390 (1988).

79. See supra note 20.

80. Mallory v. Eyrich, 666 F. Supp. 1060 (S.D. Ohio 1987), rev'd, 839 F.2d 275 (6th Cir. 1988); Chisom v. Edwards, 659 F. Supp. 183 (E.D. La. 1987), rev'd, 839 F.2d 1056 (5th Cir.), cert. denied, 109 S. Ct. 390 (1988). These courts held that Congress's use of the word "representatives" in the 
recently were these decisions reversed on appeal. ${ }^{81}$ These reversals now require election officials who seek to undervalue black votes to devise electoral methods that satisfy both the strictures of section 2 and the oneperson, one-vote doctrine. Because of the current limitations on the oneperson, one-vote doctrine, ${ }^{82}$ state officials need only apportion state judges disproportionately without altering judicial districts in order to satisfy the strictures of section 2 and to preserve an unbalanced judicial scheme. The votes of blacks in any single district would not be diluted; instead, predominately black areas simply would be assigned fewer judges than predominately white areas. ${ }^{83}$ State officials may even justify this apportionment scheme, under the current case law, by claiming that large caseloads (in white areas) demand more judges. ${ }^{84}$ Nonetheless, substantial disparities between districts should lead courts to consider whether the oneperson, one-vote principle should be applied to judicial elections when racial discrimination is established. ${ }^{85}$

Voting Rights Act indicated that $\S 2$ did not apply to judges, who, "by their very definition, do not represent voters . . . " Chisom, 659 F. Supp. at 186; see Mallory, 666 F. Supp. at 1062-63. But see Martin v. Allain, 658 F. Supp. 1183, 1200 (S.D. Miss. 1987) ("The use of the word 'representatives' in Section 2 is not restricted to legislative representatives but denotes anyone selected or chosen by popular election from among a field of candidates to fill an office, including judges."). Before 1987, however, no federal court had invalidated a judicial election scheme for violating $\$ 2$ of the Voting Rights Act.

81. Approximately one year ago, the Fifth Circuit concluded in Chisom that, since elected judges are "candidates for public or party office" and are elected by popular vote, as described in the Act, their elections are covered by $\$ 2.839$ F.2d at 1060,1059 . This analysis followed directly from the Senate Report, which emphasized that the right of a qualified voter to cast a ballot in any election is protected from vote dilution under the newly adopted results test. SENATE REPORT, supra note 19, at 2; 1982 U.S. Code Cong. \& ADMIN. NEws 177, 179 ("S. 1992 amends Section 2 of the Voting Rights Act of 1965 to prohibit any voting practice, or procedure results [sic] in discrimination.") (emphasis supplied). One of the original purposes of the Voting Rights Act was to outlaw discriminatory practices nationwide by defending a minority group's equal access to the ballot box. SENATE REPORT, supra note 19, at 6; 1982 U.S. CODE CONG. \& ADMIN. NEwS at 183. The focus of the amended Act is the political process leading to any elected office. See SENATE REPORT, supra note 19, at 7-9; 1982 U.S. Code CoNG. \& ADMIN. News at 184-86 (discussing extensions of Voting Rights Act and ability to vote); Senate Report, supra note 19, at 16; 1982 U.S. Code ConG. \& Admin. NEWS at 193 (identifying equal access to electoral processes as crucial question for judicial inquiry); SENATE REPORT, supra note 19, at 19; 1982 U.S. CODE CONG. \& ADMIN. News at 196 (mentioning Reynolds and "the right to have the ballot counted"); SENATE REPORT, supra note 19, at 28; 1982 U.S. Code Cong. \& ADMIN. NEwS at 205 (affirming right to have vote count fully); SENATE REPORT, supra note 19, at 33; 1982 U.S. CoDE CoNG. \& ADMIN. News at 211 (discussing right of minority voters "to participate meaningfully in elections"). Employing similar logic, the Sixth Circuit reached the same comclusion in Mallory. 839 F.2d at $277-81$.

82. See supra Section I(B).

83. For a discussion of the potential problems of at-large voting, see infra note 131.

84. The justifications for such claims will be discussed infra text accompanying notes $119 \& 120$.

85. This is not to suggest that every deviation from the average constitutes discrimination per se. See infra Section III(A). However, states with judicial districts composed of substantially different numbers of citizens-divided along racial lines-should be forced to justify their schemes of apportionment. Such apportionment schemes exist. Indeed, despite the fact that until recently the legality of racial gerrymandering made malapportionment unnecessary, there is evidence suggesting that at least some electoral districts provide more judges in predominantly white areas than in black areas. In Alabama's predominantly black Fourth Judicial District, for example, there are two judges for the 115,075 citizens. BNA's Directory of State Courts, Judges, and Clerks 2 (2d ed. 1988) [hereinafter BNA's Directory]; U.S. BuREau of THE Census, County and City Data Book 18 (1983) [hereinafter DATA Book]. These data are based upon the number of citizens present in 


\section{G. The Importance of Proper Judicial Apportionment and Representation}

The significance of this observation-that current antidiscrimination law does not adequately prevent the underrepresentation of blacks in judicial elections-becomes apparent when the roles of state judges are considered. As both the Chisom and Mallory courts recognized, elected judges can be regarded as "representatives" within the meaning of the Voting Rights Act. ${ }^{86}$ Each court concluded that the representative character of state judges stems from their popular election. ${ }^{87}$ However, neither court considered whether state judicial elections make judges more responsive to the actual political beliefs of their constituents. ${ }^{88}$ Such a consideration becomes crucial when assessing the consequences of malapportionment: If officials are allowed to devalue black votes through apportionment schemes designed to reduce the number of judges in predominantly black districts, black citizens will be less able than white citizens to influence the direction of jurisprudence in their judicial districts. ${ }^{89}$

each electoral district (as determined by the last census) and the number of judges seated in each district. Thus, each judge in this district serves approximately 57,538 citizens. In contrast, Alabama's predominantly white Sixth Judicial District elects five judges who serve 137,541 citizens, which amounts to 27,508 citizens per judge. See BNA's DrRecToRY, supra, at 3; DATA Book, supra, at 18. As a result, white citizens in the Sixth Judicial District are more closely represented than are black citizens in the Fourth Judicial District.

Similar statistics exist in another state that conducts partisan elections of its judges: Each judge in North Garolina's predominantly white First District represents approximately 45,000 citizens, while the only judge in the predominantly black Sixth District represents approximately 122,000 citizens. See BNA's DiRecroRY, supra, at 230-31; DATA Book, supra, at 396. Again, these data do not prove discrimination, but simply demonstrate that, in some areas, blacks are not as closely represented by judges as are whites. States establishing such districts should be compelled to justify these disparities. See infra Section III(A).

86. Chisom v. Edwards, 839 F.2d 1056, 1061-63 (5th Cir.), cert. denied, 109 S. Ct. 390 (1988); Mallory v. Eyrich, 839 F.2d 275, 279-81 (6th Cir. 1988).

87. Chisom, 839 F.2d at 1063 (characterizing representative as anyone selected by popular election); Mallory, 839 F.2d at 278 (emphasizing act of voting). Commentators have also recognized that elected state judges derive legitimacy from the fact that a majority of voters has authorized them to serve the public. Stated simply, "[t]he composition and division of the electorate is crucial. ... [T] he legitimacy of judicial institutions, processes, and decisions may turn in part on citizen participation in the election of judges. Both the size and the composition of judicial electorates bear on the legitimacy of the state courts." Adamany \& Dubois, Electing State Judges, 1976 WIs. L. REv. 731, 736 (emphasis supplied); see Bell, Principles and Methods of Judicial Selection in France, $61 \mathrm{~S}$. CAL. L. REv. 1757, 1775 (1988) ("[I]f the judges seek to apply values which are not just their own, but which are typical of a consensus in society (or perhaps in a relevant section of the community), then the decisions will be authoritative and considered legitimate.").

88. A stark characterization of the relationship between elections and judicial responsiveness was offered by former California Justice Otto Kaus, who, in discussing one case he heard, remarked: "I decided the ... case the way I saw it . . . But to this day, I don't know to what extent I was subliminally motivated by the thing you could not forget-that it might do you some good politically to vote one way or the other." L.A. Times, Sept. 28, 1986, \$ I, at 23, col. 2. West Virginia Supreme Court of Appeals Justice Richard Neely also has observed this phenomenon, noting that "the way in which state judges get their jobs has a major impact on the outcome of lawsuits." R. NEELY, THE Product Liability Mess: How Business Can Be Rescued from State Court Politics 26 (1988). See Wold \& Culver, The Defeat of the California Justices: The Campaign, the Electorate, and the Issue of Judicial Accountability, 70 Judicature 348, 351 (1987).

89. On a normative level, this Note expresses no opinion as to whether elected judges should be responsive to their "constituents." It does posit, however, that judicial elections give judicial candidates 
A brief comparison of the federal and state judiciary illustrates the representative qualities possessed by elected state judges seeking to satisfy constituents. On the one hand, the Constitution requires that the President nominate, and the Senate approve, all federal judges, ${ }^{80}$ and it permits these judges to hold office during time of good behavior. ${ }^{91}$ Exempt from election, federal judges are not directly accountable to the people. ${ }^{92}$ Conversely, the fact that states may adopt appointment, merit selection, ${ }^{83}$ or various other election schemes ${ }^{84}$ discredits the notion that state judges are as detached from politics as are their federal counterparts. ${ }^{95}$ Because

powerful incentives to act responsively to their constituents, and therefore, to some degree, to "represent" them. The question addressed by this Note, then, is not whether judges should be elected. Instead, it asks whether state officials should be allowed to apportion judges and reduce the influence of black voters vis-à-vis white voters on state court jurisprudence given a system of elected judges and the consequent representative qualities that these judges possess.

90. U.S. Const, art. II, \$2, cl. 2.

91. U.S. CoNST. art. III, $\S 1$.

92. See, e.g., P. Dubols, From Baliot to Bencr 20-28 (1980); Kurland, The Constitution and the Tenure of Federal Judges: Some Notes from History, 36 U. CHI. L. REv. 665, 667 (1969); Neuborne, The Myth of Parity, 90 Harv. L. Rev. 1105, 1127-28 \& n.80 (1977). Benjamin Cardozo, however, criticized the traditional argument that judges are merely law-appliers: "Everywhere," wrote Cardozo, "there is growing emphasis on the analogy between the function of the judge and the function of the legislator." B. Cardozo, The Nature of THe Judictal Process 119 (1921); see also P. Dubors, supra, at 23 ("IJ]udges not only make conscious policy choices in the adjudication of cases and in the exercise of the power of judicial review, but also engage in political decision-making as a matter of function."). The Legal Realists also attacked the notion that any judge can act entirely without regard to lawmaking. See, e.g, J. Frank, LAw and THE MOdern Mind 32-41 (1936). These critics challenged the oracular theory of judging, developed in this country largely by Chief Justice Marshall, which held that judges properly "'found' rather than 'made' law. . . " G. WHITE, supra note 58 , at 47.

93. Merit selection is a process whereby a nominating commission, consisting of members appointed by the governor, supplies a list of qualified nominees from which the governor must make his appointment. In a typical merit selection system, following a judge's appointment by the governor, voters have the option of retaining or rejecting each individual judge when his term expires. P. DuBois, supra note 92 , at 4 . For a recent defense of the merit selection plan, see Hill, Taking Texas Judges Out of Politics: An Argument for Merit Election, 40 BAYLOR L. REv. 339 (1988) (written by former Chief Justice of Texas Supreme Court).

94. Eligible voters in ten states-Alabama, Arkansas, Illinois, Mississippi, New Mexico, North Carolina, Pennsylvania, Tennessee, Texas, and West Virginia-may cast a ballot in partisan elections for judges on the State Supreme Court. Applebome, Texas Court Fight Puts Focus on Elected Judges, N.Y. Times, Jan. 22, 1988, at B4, col. 3. In partisan elections, voters are provided with the party label for each judicial candidate on the ballot. Conversely, thirteen states-Georgia, Idaho, Kentucky, Louisiana, Michigan, Minnesota, Montana, Nevada, Ohio, Oregon, North Dakota, Washington, and Wisconsin-have adopted non-partisan elections for positions on the State Supreme Court, and the remaining states use some form of appointment. Id. This abstract is painted with a broad brush: Because of the unique selection procedures in each state-and the fact that states may elect some judges and appoint others-it is not possible to generalize with any degree of precision about each state's election practices. For a more detailed description of the electoral systems used by each state, see 27 The Council of State Governments, The Book of the States 163-65 (1988) [hereinafter Book of STATES].

95. See P. Dubols, supra note 92 , at 20 . The debate regarding elected judges is summarized neatly in 4 The Reference Shelf, Election Versus Appointment of Judges (L. Beman ed. 1926). Indeed, the Jacksonian movement toward broadened suffrage and popular control led to the adoption of electoral systems for judges in many states. L. FrIEDMAN, A HISTORY OF AMERICAN Law 126-27 (2d ed. 1985). But of. The Federalist No. 78, at 471 (A. Hamilton) (C. Rossiter ed. 1961) (If the power to elect judges were given to the people, "there would be too great a disposition to consult popularity to justify a reliance that nothing would be consulted but the Constitution and the laws."). 
judges may be removed from the bench in state elections, Burt Neuborne has posited that "when arguable grounds supporting the majoritarian position exist, state trial judges are far more likely to embrace them than are federal judges." ${ }^{\text {98 }}$ Indeed, elections produce judges who may be more responsive to the concerns of the people than are appointed judges. ${ }^{97}$

Of course, the amount of pressure felt by a state court judge in render-

96. Neuborne, supra note 92, at 1128; see P. DuBors, supra note 92, at 31 (elected judges must respond to their constituents or be defeated); Jacob, Judicial Insulation-Elections, Direct Participation, and Public Attention to the Courts in Wisconsin, 1966 Wrs. L. REv. 801, 801; Ladinsky \& Silver, Popular Democracy and Judicial Independence: Electorate and Elite Reactions to Two Wisconsin Supreme Court Elections, 1967 WIS. L. Rev. 128; Nagel, Political Party Affiliation and Judges' Decisions, 55 AM. PoL. ScI. Rev. 843, 849 (1961). Of course, it should be acknowledged that even appointed judges, whether federal or state, may be compelled to temper their political beliefs during the appointment process. Partisanship plays a major role in the selection (or rejection) of federal judges; the recent nomination and confirmation battle of Judge Robert Bork demonstrates the importance of judicial ideology as well as competence. Likewise, it is hardly insignificant that nearly all the federal judges named since the Civil War have been nominated from the President's party. Adamany \& Dubois, supra note 87, at 773-74; see S. NAgel, CoMparing Elected AND APPOINTEd Judicial Systems 24 (American Politics Series No. 04-001, 1973). By 1987, more than 93\% of President Reagan's judicial appointments were Republicans, compared with President Carter's appointments, approximately $92 \%$ of whom were Democrats. Goldman, Reagan's Second Term Judicial Appointments: The Battle at Midway, 70 Judicature 324, 328 (1987). Politics are no less important in state appointments: Most appointed state judges are also named from the governor's party. Adamany \& Dubois, supra note 87 , at 774. See S. NAGEL, supra, at 24 . One commentator has written that " [i]t is well known that those who achieve the appointed bench often move through the same political channels, i.e., you know the Governor, or you know someone who knows the Governor, as those who reach the bench by way of the elective process.' "Vance, Elected or Appointed, Our Judges Are Still Politicians: The 'Independence of the Judiciary' Lies in the Eyes of the Beholder, L.A. Daily J., Sept. 5, 1983, at 4, col. 3.

97. One commentator hypothesizes that state elected judges often make decisions that reflect specific views held by their communities. Gibson, Environmental Constraints on the Behavior of Judges: A Representational Model of Judicial Decision Making, 14 LAw \& Soc'y REv. 343, 358 (1980). According to this study, the sentencing behavior of elected judges is correlated directly to the nature of their communities. This analysis is supported further by the fact that sentencing variations within individual counties are demonstrably smaller than variations across counties. This is not to suggest that only elected judges are sensitive to community pressure. However, elections provide direct incentives for judges to consider community sentiments before deciding prominent cases. Cf. A. BENTLEY, The Process of Government 393 (1949) (judicial responsiveness to public pressure is evidence of this representation). Furthermore, Beverly Cook and Walter Markham found correlations between sentences for draft evasion and characteristics of different judicial districts. Cook, Sentencing Behavior of Federal Judges: Draft Cases-1972, 42 U. CiN. L. Rev. 597 (1973); W. Markham, Draft Offenders in the Federal Courts: A Search for the Social Correlates of Justice (1972) (Ph.D. dissertation, University of Pennsylvania). Conversely, because federal judges cannot be held accountable through elections for their decisions, their jurisprudence tends to reflect the ideology of the appointing President. S. Goldman \& T. Jahnige, The Federal Courts as a Political System 76 n.80, 134-84 (3d ed. 1985).

It also should be noted that the sociological characteristics of state judges can be correlated with their decisions. One study concluded, for example, that Democratic judges tend to exhibit greater support than Republican judges for criminal defendants. D. Bowen, The Explanation of Judicial Voting Behavior from Sociological Characteristics of Judges 57-58 (1965) (Ph.D. dissertation, Yale University). Bowen's finding discredits the Mallory district court's pronouncement that all litigants can expect similar treatment in state court, regardless of a judge's race, politics, or religion. See Mallory v. Eyrich, 666 F. Supp. 1060, 1063 (S.D. Ohio 1987) ("No one can seriously assert that white litigants should fare better before a white elected judge and black litigants . . . under a black elected judge."), rev'd, 839 F.2d 275 (6th Cir. 1988). However, two commentators recently opined that a federal judge's race has little effect upon her jurisprudence, though they also acknowledged the statistical limitations of their analysis. Walker \& Barrow, The Diversification of the Federal Bench: Policy and Process Ramifications, 47 J. Pol. 596, 608, 615 (1985). 
ing a decision will be influenced directly by the method of judicial election utilized by the individual state. Judges elected by partisan election ${ }^{98}$ are most susceptible to direct pressure. ${ }^{99}$. In states holding a combination of non-partisan selection and retention elections, ${ }^{100}$ and in states with merit retention systems, ${ }^{101}$ it is much more difficult for voters to cast ballots based upon party ideology. ${ }^{102}$ Even in these elections, nonetheless, politics still plays a role in judicial elections, and thereby challenges judicial independence. ${ }^{103}$

These methods of judicial selection all touch directly upon issues of politics and representation. ${ }^{104}$ As a result, elected judges must be appor-

98. See BooK of STATES, supra note 94, at 163-65 (listing methods of selection and retention of judges for each state).

99. In states employing a partisan ballot, voters tend to cast ballots along party lines. Adamany \& Dubois, supra note 87, at 760; see also P. DuBors, supra note 92, at 144 (partisan elections clearly structure voter choices). A survey conducted of states using the partisan ballot indicates that the mean party correlation between gubernatorial and judicial elections is substantial. Id. at 74-75. Furthermore, partisan elections compel judges to rely indirectly on party apparatuses for support. Id. at 148 . Party organizers also supply the organization and resources needed to finance a successful campaign. Without these resources, a candidate may lose to a well-heeled opponent; with them, a judicial candidate may carry significant debts, both financial and personal, to the bench. See Applebome, supra note 94 (Texas Supreme Court Justices criticized for accepting campaign contributions from Pennzoil before refusing to hear appeal of $\$ 10.53$ billion judgment for Pennzoil); see also R. NEELY, supra note 88, at 62 (local plaintiffs, who can vote in state judicial elections, enjoy advantage in state court over out-of-state defendants, who "can't even be relied upon to send a campaign contribution.").

100. BOoK oF STATES, supra note 94. Generally, two variations of the non-partisan election exist: first, the partisan election followed by non-partisan retention elections (mixed system), and second, the non-partisan election followed by non-partisan retention (pure system). In a mixed system, voters are provided with a party label for the initial election but are given no such guidance in subsequent elections. P. Dubors, supra note 92 , at $81,89$.

101. See Book of STATES, supra note 94 .

102. P. Dubols, supra note 92, at 75-77; see Adamany, The Party Variable in Judges' Voting: Conceptual Notes and a Case Study, 63 AM. PoL. Scr. Rev. 57, 69-71 (1969). But see Adamany \& Dubois, supra note 87, at 760 ("In states, such as Michigan and Ohio, with significant elements of partisanship in nominating procedures and campaigning, but with nonpartisan election ballots, votes are cast mainly along party lines."). Perhaps most important in this calculus is the fact that few judges are defeated in retention campaigns. Hall \& Aspin, What Twenty Years of Judicial Retention Elections Have Told Us, 70 Judrcature 340, 346 (1987); see Lovrich \& Sheldon, Voters in Judicial Elections: An Attentive Public or an Uninformed Electorate?, 9 Just. Sxs. J. 23, 24-25 (1984).

103. The politics that may be involved in the merit retention system can be illuminated by briefly examining the popular campaign to unseat California Supreme Court Chief Justice Rose Bird in the 1986 California retention election. Perhaps the primary issue leading to Justice Bird's defeat was her record in criminal cases. Critics charged that she had been soft on criminals and had refused to implement the death penalty where warranted. Wold \& Culver, supra note 88, at 349-50. The campaign literature used by these critics to remove Justice Bird was highly political. One piece of literature sent to California voters inquired whether "'you want a Supreme Court that will be dominated by the extremisl left-wing philosophy of Jerry Brown, Tom Hayden, and Jane Fonda?" "Id. at 350. Pre-election spending resembled an ordinary campaign among senators and representatives: Pro- and anti-Bird forces spent approximately seven and one-half million dollars on the retention election. Id. at 350-51. For a summary of this campaign, see Thompson, Judicial Retention Elections and Judicial Method: A Retrospective on the California Retention Election of 1986, 61 S. CAL. L. Rev. 2007, 2036-42 (1988). But see Hall \& Aspin, supra note 102, at 342 (retention elections are typically uneventful; fewer than fifty trial judges have been defeated in last 50 years).

The merit selection scheme can be quite political in at least one respect: Governors typically nominate to merit selection commissions individuals who share their political philosophies. Consequently, the list of qualified candidates compiled by most commissions tends to resemble any list the governor would create independently.

104. Nagel, supra note 96 , at 850 : 
tioned evenly to ensure that they "represent" a valid cross-section of the community. Unlike the federal process, state judges may be forced either to explain their judicial philosophies to the electorate (through their election committees) or to temper their jurisprudence for the next election. Neither response facilitates an independent or detached state judiciary. Both are characteristic of the "governmental functions" performed by elected judges, and both help explain why the one-person, one-vote principle should be extended to judicial elections when, particularly in racial discrimination cases, these elections are challenged.

\section{The Proposal: Extending the One-Person, One-Vote Principle to Racially Discriminatory ApPortionment Systems}

Refusing to extend the one-person, one-vote principle to elected judges undermines recent advances in antidiscrimination law. The newly amended Voting Rights Act prohibits the dilution of votes based upon race by regulating the popular composition of discrete judicial districts. What it has not regulated, however, is the number of judges assigned to each district. ${ }^{105}$ Indeed, federal courts thus far have relied on the Supreme Court's decision in Wells in refusing to apply the one-person, one-vote principle to judicial elections. ${ }^{108}$ This Note has argued that such reliance is misplaced, because the Court in Wells was not presented with discrimination based upon race; it simply considered the presumptively race-neutral allocation of judges within a state. The Note has also traced the history of the oneperson, one-vote principle, and determined that some of the earliest relevant cases extended the principle to cases involving racial discrimination. ${ }^{107}$ These analyses suggest that courts considering racial discrimination claims should not simply defer to Wells, but should instead determine whether a separate standard applies to one-person, one-vote cases based upon race.

Regardless of judicial tenure and modes of selection, there probably will always be a residue of party-correlated judicial subjectivity so long as political parties are at least partly valueoriented and so long as court cases involve value-oriented controversies. Ultimately the problem becomes not how to remove this irreducible residue of judicial subjectivity, but rather what direction it take should [sic].

For a similar view, see Thompson, supra note 103, at 2062 ("As governors . . . come to view the bench as the area in which there [sic] partisan philosophies will be carried out over the long run by judges deciding cases to advance a political agenda, retention elections can become more and more partisan.").

105. Nor has it required that judicial districts conform to the de minimis variance doctrine. Martin v. Mabus, 700 F. Supp. 327, 332 (S.D. Miss. 1988); for a discussion of this doctrine, see infra note 116 and accompanying text.

106. See supra note 63.

107. See supra notes $65-72$ and accompanying text. 


\section{A. The Standard}

This Note proposes that courts closely scrutinize discriminatory judicial election systems that violate the one-person, one-vote principle. This approach comports with the Fourteenth Amendment by guaranteeing the equal protection of the fundamental right to vote. ${ }^{108}$ Such a test would proceed along typical lines of a close scrutiny analysis in voting rights challenges: Judicial apportionment schemes that have "a real and appreciable impact on the exercise of the franchise . . . must be 'closely scrutinized' and found reasonably necessary to the accomplishment of legitimate state objectives in order to pass constitutional muster." 100

Under traditional equal protection analysis, claimants may not challenge a law simply because it adversely affects them; rather they must demonstrate the existence of intentional discrimination. ${ }^{110}$ This requirement presumably also applies to challenges of judicial election schemes. ${ }^{111}$ However, in the voting rights area, the Court has allowed proof of intent to be introduced through "indirect" evidence: "Necessarily, an invidious discriminatory purpose may often be inferred from the totality of the relevant facts, including the fact, if it is true, that the law bears more heavily on one race than another." "112 Indeed, in formulating the one-person, one-vote doctrine, the Supreme Court has emphasized the numerical discrepancies between districts rather than intent. The notion of discriminatory intent was not stressed in the Court's Reynolds conclusion: "[A]n individual's right to vote for state legislators is unconstitutionally impaired when its weight is in a substantial fashion diluted when compared with

108. Harper v. Virginia Bd. of Elections, 383 U.S. 663 (1966) (invalidating poll tax as violative of equal protection clause); $c f$. Yick Wo v. Hopkins, 118 U.S. 356, 370 (1886) (right to vote is fundamental because it is preservative of all other rights). See generally Wall, Equal Protection: Analyzing the Dimensions of a Fundamental Right-The Right to Vote, 17 SANTA Clara L. Rev. 163 (1977).

109. Bullock v. Carter, 405 U.S. 134, 144 (1972). But cf. Gunther, The Supreme Court, 1971 Term-Forward: In Search of Evolving Doctrine on a Changing Court: $A$ Model for a Newer Equal Protection, 86 HARv. L. Rev. 1, 8 (1972) (heightened scrutiny may be " 'strict' in theory [but] fatal in fact ....."). Conversely, if an election system does not have a "real or appreciable impact" on the exercise of the franchise, it would be subject only to "rational basis" scrutiny, in which the government would have to prove only that the system has a "rational basis." See In re Objections to Nomination Petition of Cavanaugh, 65 Pa. Commw. 620, 636-37, 444 A.2d 1308, 1311 (1982). It is clear, however, that an apportionment scheme that allocates judges based upon race would have a "real or appreciable impact" on the ability of blacks to vote for candidates of their choice.

110. See, e.g., Arlington Heights v. Metropolitan Hous. Dev. Corp., 429 U.S. 252, 265 (1977); Washington v. Davis, 426 U.S. 229, 240 (1976).

111. See Arlington Heights, 429 U.S. at 265; Washington v. Davis, 426 U.S. at 240 (showing of discriminatory intent required in all equal protection cases).

112. Rogers v. Lodge, 458 U.S. 613, 618 (1982) (quoting Washington v. Davis, 426 U.S. at 242). In Rogers, the Court affirmed a district court's finding that voting officials conducted at-large elections for the invidious purpose of diluting black voting strength. The Court noted that although blacks constituted a majority in the challenged district, they constituted a distinct minority of registered voters. In addition, the existence of bloc voting along racial lines and the absence of black elected officials led the court to conclude that "[t]hese facts bear heavily on the issue of purposeful discrimination." 458 U.S. at 623 (emphasis supplied). 
votes of citizens living in other parts of the State."113 Similar language appearing a few pages later in Lucas $v$. Forty-Fourth General Assem$b l y$ 114 led Professor Tribe to write that "Lucas imposed upon the state the burden of justifying deviations from the equal population standard. The imposition of this burden was of singular practical importance, given the difficulty of proof and argument in matters so elusive as proper representation."115

Essentially, plaintiffs challenging state apportionment schemes must demonstrate the existence of significant population disparities in order to maintain an action. ${ }^{116}$ Once this showing has been made, the state may present evidence-as a defense to disproportionate districting-that discrepancies are necessary in order to achieve a legitimate state goal. ${ }^{117}$ Such evidence will not be dispositive if the announced goal does not necessitate the current level of deviation. ${ }^{118}$

Perhaps the most legitimate state objective served by malapportionment of elected judges is the importance of locating judges in areas where their services are required. To be sure, judges must "be conveniently located to those people whom they serve. Location, then, is one of many significant factors which the legislature may properly consider when carrying out its constitutional mandate to create an effective judicial system."119 Many courts relied upon this factor in dismissing one-person, one-vote claims in disputed judicial elections. ${ }^{120}$

Nonetheless, it is not clear that this factor should, without further analysis, be "found reasonably necessary" to achieve legitimate state ends in every district. Courts must ascertain in each case whether the speedy administration of justice requires the apportionment of more judges in jurisdictions predominantly composed of white citizens, instead of simply oper-

113. Reynolds v. Sims, 377 U.S. 533, 568 (1964); see id. at 579. The Reynolds Court went on to hold that "the Equal Protection Clause requires that a State make an honest and good faith effort to construct districts, in both houses of its legislature, as nearly of equal population as is practicable." Id. at 577. Again, intent plays no role in this calculation. This emphasis on numerical consistency has been followed well after Washington v. Davis. See, e.g., Karcher v. Daggett, 462 U.S. 725 (1983).

114. 377 U.S. 713 (1964).

115. L. TRIBE, supra note $12, \S 13-3$, at 1066.

116. As a general matter, courts tolerate disparities of less than $10 \%$ as acceptable de minimis deviations. See, e.g., Brown v. Thomson, 462 U.S. 835, 842 (1983) (deviations of $10 \%$ in state legislative districts permissible); Connor v. Finch, 431 U.S. 407, 418 (1977) (deviations below $10 \%$ permissible); Gaffney v. Cummings, 412 U.S. 735, 750-51 (1973) (deviations of 7.83\% in Connecticut legislative districts permissible). "[L]arger disparities in population, however, create[] a prima facie case of discrimination and therefore must be justified by the State." Brown v. Thomson, 462 U.S. at 842-43; see Kirkpatrick v. Preisler, 394 U.S. 526, 531 (1969); Swann v. Adams, 385 U.S. 440, 444 (1967); Reynolds v. Sims, 377 U.S. 533, 562-63 (1964).

117. Brown v. Thomson, 462 U.S. at 843 ; Mahan v. Howell, 410 U.S. 315, 328, modified, 411 U.S. 922 (1973); Reynolds v. Sims, 377 U.S. at 579.

118. Kilgarlin v. Hill, 386 U.S. 120, 123 (1967).

119. Buchanan v. Rhodes, 249 F. Supp. 860, 865 (N.D. Ohio 1966).

120. See Holshouser v. Scott, 335 F. Supp. 928, 932 (M.D.N.C. 1971); New York State Ass'n of Trial Lawyers v. Rockefeller, 267 F. Supp. 148, 153 (S.D.N.Y. 1967); Stokes v. Fortson, 234 F. Supp. 575, 577 (N.D. Ga. 1964). 
ating under this assumption. ${ }^{121}$ This assessment becomes critical in jurisdictions predominantly composed of minorities who may face overcrowded dockets in their own districts. In order to deal with such dockets, courts may be compelled to limit the discovery process, or minorities may be forced to take their cases to other districts (assuming liberal venue requirements) to appear before judges chosen by an entirely different constituency. ${ }^{122}$ All these measures substantially impair the certainty of justice for black citizens who reside in these unequal districts.

\section{B. Why Close Scrutiny?}

This Note advocates the adoption of a close scrutiny standard in oneperson, one-vote cases brought by plaintiffs alleging racial discrimination. It is primarily because of the importance of these elections to all citizens-and particularly to blacks-that courts should not simply defer to legislatively-created judicial districts.

Citizens are confined exclusively to the ballot box when exercising judgment over the selection of elected judges. ${ }^{123}$ As a result, the right to cast a meaningful vote for these positions is particularly important in states where black voters are heavily concentrated in specific geographical areas but are outnumbered in the state as a whole. If election officials are allowed to allocate fewer judges to these areas, blacks will be able to exercise little influence over the process of judicial selection, even in areas where they comprise a supermajority of eligible voters. ${ }^{124}$ Thus, the notion of close scrutiny is particularly appropriate because two fundamental rights are burdened: the right to vote, and the right of minorities not to be subjected to discrimination. ${ }^{125}$

Furthermore, underrepresentation of blacks in judicial districts is especially troubling when considered within the framework of the legal profession. Even today, this country has relatively few black attorneys and

121. Courts must also determine whether the current level of deviation is required to achieve the speedy administration of justice. See supra note 118 and accompanying text.

122. Of course, burdensome litigation costs, including those caused by delay or venue changes, may also dissuade many from filing suits.

123. See Letter from Steve Suitts, Executive Director of the Southern Regional Council, to Professor Drew S. Days, III (June 28, 1988); of. United States v. Carolene Prods. Co., 304 U.S. 144, 152-53 n.4 (1938) ("[L]egislation which restricts those political processes which can ordinarily be expected to bring about repeal of undesirable legislation, is to be subjected to more exacting judicial scrutiny under the general prohibitions of the Fourteenth Amendment than are most other types of legislation.").

124. The presence of disproportionate judicial districts undermines the principle that each state court district, whether populated by white or black voters, is but one equal part of the whole state court system.

125. See L. TRIBE, supra note 12, § 16-6. All forms of gerrymandering and apportionment are subject to some level of scrutiny, but the Court has not applied close scrutiny to many of these cases. See, e.g., Mahan v. Howell, 410 U.S. 315, 340-41, modified, 411 U.S. 922 (1973); Reynolds v. Sims, 377 U.S. 533 (1964); Casper, Apportionment and the Right to Vote: Standards of Judicial Scrutiny, 1973 Sup. Cr. Rev. 1. 
judges. ${ }^{128}$ Some commentators have suggested that the lack of racial diversity in the legal profession has manifested itself in a system of laws that is unresponsive to the needs of minorities. ${ }^{127}$ Adopting an electoral system that broadens the judicial base would help increase the judiciary's awareness of the needs of those historically disadvantaged by the legal profession and the law. ${ }^{128}$ Conversely, if election officials are allowed to apportion fewer judges to predominantly black areas, blacks will be less able to elect judges most sensitive to their concerns.

The elective judicial system is also better served when judges comprise a cross-section of their communities. "A basic tenet of the American legal system is government of the people-all the people. Therefore, it seems reasonable to expect that those persons who are primarily responsible for making the legal system function-our lawyers and judges-represent a valid cross-section of all the people."129 Broadening the composition of the bench is especially important because judicial background characteristics can affect fact-finding and sentencing decisions. ${ }^{\mathbf{1 3 0}}$

Not surprisingly, blacks also participate in elections more frequently when their votes are counted equally. At least one study has confirmed that dilutionary elections, for example, lead systematically to a reduction in black political participation. ${ }^{131}$ It is likely, therefore, that black partici-

126. Only approximately $3 \%$ of the nation's attorneys and judges are black, although blacks comprise nearly $10 \%$ of the workforce. U.S. BUREAU OF THE GenSUS, Statistical ABSTRACT of THE UnITED STATES: 1988, at 376 (108th ed. 1987); see also Sherman, Is Mississippi Turning?, Nat'L. L.J., Feb. 20, 1989, at 1, 24 ("As of 1986, the last year for which figures are available, there were only 727 black state court judges, or 2.6 percent of the total. . . .").

127. See, e.g., D. Bell, AND We ARe Not SAved (1987); D. Bell, RaCe, Racism, and AMERICAN LAW 207-77 (2d ed. 1980); Coalition of Concerned Black Americans, A Preliminary Report of the Experience of the Minority Judiciary in the City of New York, 18 How. L.J. 495 (1975).

128.

[T] ities and women cannot help but add a new dimension of justice to our own courts in most instances.

These judges cannot help but educate their colleagues by the example they set, by the creation of precedents, and by informal as well as formal interchange.

Goldman, Should There Be Affirmative Action for the Judiciary?, 62 Judicature 488, 494 (1979). Cf. Spire, The Much Needed and Long Overdue Broadening of the Legal Profession: An Address from the Bar, 37 CReIGHTON L. REv. 799, 808 (1984) (oppressive nature of law requires diverse representation within legal profession).

129. The Black Judge in America: A Statistical Profile, 57 Judicature 18, 18 (1973); see AMERICAN ENTERPRISE INSTITUTE, Whom Do Judges REPRESENT? 15 (1981) (quoting Dr. Sheldon Goldman); Adomeit, Selection by Seniority: How Much Longer Can a Custom Survive that Bars Blacks and Women from the Connecticut Supreme Court?, 51 CoNN. B.J. 295, 321 (1977) ("It should be as important for blacks and women to be represented in the judiciary as in the legislature or in the executive department.").

130. See H. JaCOB, Justice in AMerica 120-23 (3d ed. 1978); Adamany, supra note 102.

131. Latimer, Black Political Representation in Southern Cities, 15 URB. AFF. Q. 65, 80-81 (1979). In this study, voter turnout in the heavily black district of Auburn, Alabama, rose sharply after dilutionary election schemes were altered. Id. at 80 . As a result, blacks were elected to Auburn's city council for the first time. Id. ("The district election system apparently not only 'allowed' black representation, it also stimulated black voting turnout.") (citation omitted). Professor Latimer's study considered the dilutionary effects of "at-large elections"; this term describes voting schemes that combine a number of discrete districts into one electoral unit. See Note, Alternative Voting Systems as 
pation in the process of electing state judges will increase when blacks are allowed to cast meaningful ballots. ${ }^{132}$

Finally, a diverse judiciary may lead to greater public confidence in the legal system, ${ }^{133}$ especially among the poor and historically disadvantaged. Many of these citizens currently regard the American system of justice, from policeman to judge to warden, as a victimizer of minorities. ${ }^{134} \mathrm{Mi}-$ norities will have more faith in the present system of justice if they are able to play a meaningful role in the electoral process. ${ }^{135}$

\section{CONCLUSION}

Courts should afford one-person, one-vote protections to citizens whose votes have been undervalued in judicial elections because of race. The adoption of a close scrutiny standard in these elections would comport with constitutional principles of antidiscrimination derived from the early one-person, one-vote cases. Such a standard would also close the loophole left in voting rights law by the recent pronouncements of two courts of appeals. If state judges are selected by popular election, each citizen must have an equal opportunity to cast a meaningful ballot. Otherwise, the disenfranchisement of individuals through judicial malapportionment will continue to vitiate the legitimacy of state judicial institutions.

Remedies for Unlawful At-Large Systems, 92 YALE L.J. 144, 144 n.1, 145 n.8 (1982). At-large electoral schemes do not constitute a per se violation of the equal protection clause of the Fourteenth Amendment. E.g., Whitcomb v. Chavis, 403 U.S. 124, 142 (1971); Seastrunk v. Burns, 772 F.2d 143, 150 (5th Cir. 1985). These electoral schemes violate the Constitution, however, if they are "conceived or operated as purposeful devices to further racial discrimination." Rogers v. Lodge, 458 U.S. 613, 617 (1982) (quoting Whitcomb, 403 U.S. at 149).

132. See Note, Affirmative Action and Electoral Reform, 90 YALE L.J. 1811, 1826 (1981) (structural electoral reform may increase minority representation).

133. AMERICAN ENTERPRISE INSTITUTE, supra note 129, at 22.

134. See McCleskey v. Kemp, 481 U.S. 279, 344 (1987) (Brennan, J., dissenting) (racism still pervasive in administration of justice); Coalition of Concerned Black Americans, supra note 127, at 495-96.

135. Note, supra note 132 , at 1826 . 
